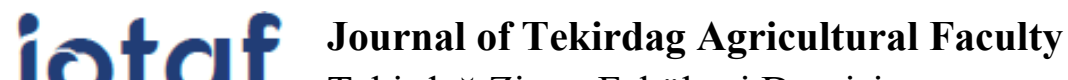 Tekirdağ Ziraat Fakültesi Dergisi}

Ocak/January 2022, 19(1)

Başvuru/Received: $31 / 05 / 21$

Kabul/Accepted: 06/10/21

DOI: $10.33462 /$ jotaf. 945904

http://dergipark.gov.tr/jotaf

http://jotaf.nku.edu.tr/

ARAŞTIRMA MAKALESI

RESEARCH ARTICLE

\title{
Determination of Nitrogen Leaching Under Precipitation Conditions from Weighted Lysimeter Planted Walnut (Juglans regia L.)
}

Tartılı Lizimetreye Dikilmiş Cevizden (Juglans regia L.) Yağış Koşullarında Yıkanan Azotun Belirlenmesi

\section{Özgür KARAKUŞ ${ }^{1 *}$, Cafer GENÇOĞLAN ${ }^{2}$, Serpil GENÇOĞLAN ${ }^{3}$}

\begin{abstract}
Many minerals such as especially nitrogen leaching out from the soil in exceed precipitation leach. This situation is a very important factor causing economic losses and environmental pollution. The aim of the study is to determine amount of the nitrogen leaching from the soil by precipitation outside the irrigation season from a weighing lysimeter controlled by a programmable logic controller (PLC). The research was carried out under Kahramanmaraş conditions in the five-month period between December 2018 - April 2019. In the study, a weighed lysimeter with a diameter of $113 \mathrm{~cm}\left(1 \mathrm{~m}^{2}\right)$ and a depth of $130 \mathrm{~cm}$ was used and on which three-year-old (Maraş 18) walnut was planted. Two pluviometers were used to measure the amount of precipitation falling on lysimeter and the drained water from it. At the beginning of the experiment, $300 \mathrm{gr}$ DAP (diammonium phosphate) fertilizer was applied to the lysimeter soil. A PLC automation system has been created that controls lysimeter and pluviometers for the research. The PLC automation system measured a total precipitation of $868.1 \mathrm{~mm}$ and drainage water of $686.6 \mathrm{~mm}$ Nitrogen concentrations and loads in the drainage water were determined from 26 water samples taken in the experimental period. In analysis of water samples, it was determined that nitrogen of $12.7 \mathrm{~kg}$ was leached from the soil of one hectare with the effect of precipitation. The leaching amount of nitrogen was $8.4 \%$, of which $24 \%$ was in the form of ammonium $\left(\mathrm{NH}_{4}\right)$ and $76 \%$ in the form of nitrate $\left(\mathrm{NO}_{3}\right)$. The highest nitrogen leached with $5.4 \mathrm{~kg}$ per hectare in December, when the precipitation was the highest $(264.1 \mathrm{~mm})$. According to the results, as amount of precipitation increased, the leaching amount of nitrogen increased leach. Therefore, application programs of nitrogen fertilizer should be prepared by taking into consideration the precipitation regime of the region. It is very important for economy, the environment and human health.
\end{abstract}

Keywords: Drainage water, Nitrogen leaching, Lysimeter, Pluviometer, Precipitation

\footnotetext{
1*Sorumlu Yazar/Corresponding Author: Özgür Karakuş, Apricot Research Institute, Malatya, TURKEY. E-mail: karakusozgur@tarimorman.gov.tr (D) OrcID: 0000-0002-4197-7008

${ }^{2}$ Cafer Gençoğlan, University of Kahramanmaraș Sütçü İmam, Agricultural Faculty, Biosystem Engineering Department, Kahramanmaraș, TURKEY. E-mail: gencoglan@ksu.edu.tr (iD) OrcID: 0000-0002-4559-4354

${ }^{3}$ Serpil Gençoğlan, University of Kahramanmaraş Sütçü İmam, Agricultural Faculty, Biosystem Engineering Department, Kahramanmaraş, TURKEY. E-mail: sgencoglan@ksu.edu.tr (iD) OrcID: 0000-0002-7390-8365

Atıf/Citation: Karakus, Ö., Gençoğlan, C., Gençoğlan, S. Determination of Nitrogen Leaching Under Precipitaiton Conditions from Weighted Lysimeter Planted Walnut (Juglans regia L.). Tekirdağ Ziraat Fakültesi Dergisi, 19 (1), 192-203.

*Bu çalışma Yüksek Lisans tezinden özetlenmiştir.

CBu çalışma Tekirdağ Namık Kemal Üniversitesi tarafından Creative Commons Lisansı (https://creativecommons.org/licenses/by-nc/4.0/)

kapsamında yayınlanmıştır. Tekirdağ 2022 


\section{$\overline{\mathbf{O} z}$}

Uzun süreli yağışlar başta azot olmak üzere birçok mineral maddenin topraktan yıkanarak uzaklaşmasına neden olmaktadır. Bu durum ekonomik kayıplara ve çevre kirliliğine neden olan çok önemli bir faktördür. Çalışmanın amacı, programlanabilir mantık denetleyici (PLC) tarafından kontrol edilen bir tartılı lizimetreden sulama sezonu dışında meydana gelen yağışların etkisiyle topraktan yıkanan azotu belirlemektir. Bu araştırma, Kahramanmaraş ili koşullarında, sulamanın yapılmadığı Aralık 2018 - Nisan 2019 aylarını kapsayan beş aylık bir dönemde gerçekleştirilmiştir. Araştırmada, üzerinde üç yaşında ceviz fidanı (Maraş 18) bulunan, $113 \mathrm{~cm}$ çapında $\left(1 \mathrm{~m}^{2}\right)$ ve $130 \mathrm{~cm}$ derinliğinde olan bir tartılı lizimetre kullanılmıştır. Bu lizimetreye yağışla giren ve sızarak uzaklaşan su miktarlarını ölçmek için iki farklı plüviyometre kullanılmıştır. Deneme başlangıcında lizimetre toprağına $300 \mathrm{gr}$ DAP (diamonyum fosfat) gübresi uygulanmıştır. Araştırma için lizimetreyi ve plüviyometreleri kontrol eden bir PLC otomasyon sistemi oluşturulmuştur. Oluşturulan bu otomasyon sistemi kullanılarak, araştırma dönemi boyunca toplam $868.1 \mathrm{~mm}$ yağış ve $686.6 \mathrm{~mm}$ drenaj ölçülmüştür. Aynı dönem içerisinde alınan 26 adet su örneklerinden drenaj suyu içerisindeki azot konsantrasyonları ve yükleri belirlenmiştir. Su örneklerinde yapılan analizlerde yağışların etkisiyle hektardan $12.7 \mathrm{~kg}$ azotun topraktan yıkanarak uzaklaştığı belirlenmiştir. Belirlenen bu değer, başlangıçta lizimetre toprağında bulunan toplam azotun \% 8.4'ü olup bu değerin \%24'ü amonyum $\left(\mathrm{NH}_{4}\right)$ ve \%76'sı nitrat $\left(\mathrm{NO}_{3}\right)$ formundadır. En fazla azot yıkanması, yağışların en fazla olduğu Aralık ayında (264.1 mm) hektarda $5.4 \mathrm{~kg}$ olarak gerçekleşmiştir. Elde edilen bu sonuçlara göre artan yağış miktarları topraktan yıkanan azot miktarlarını artırmıştır. Bu yüzden azotlu gübre uygulama programları, bölgenin yağış rejimi dikkate alınarak hazırlanmalıdır. Bu durum çevre ve insan sağlığı açısından çok önemlidir.

Anahtar Kelimeler: Azot yıkanması, Drenaj suyu, Lizimetre, Plüviyometre, Yağış, 


\section{Introduction}

Nitrogen is a very important plant nutrient being in organic and inorganic forms in the soil (Prakasa Rao and Puttanna, 2000). The reason for this is that it takes place in the structure of organic compounds with important functions such as amide, amino acid, chlorophyll, protein and nucleic acid (Müftüoğlu and Demirer, 1998). Although it is an important source of nutrients in crop production, improper fertilizer applications can cause significant harm in terms of health, environment and economy (Çetin et al., 2020). Agricultural pollution is more difficult to control than other pollution (Sünal, 2012). Therefore, in order to reduce the negative effects of nitrogen, it is necessary to analyze its behavior in the soil well (Güzel et al., 2008).

When nitrogen is not taken up by plants, by being carried along with rainfall, and surface and irrigation water it can cause eutrophication in surface water, nitrate accumulation in underground water, acid rain in gas form and environmental problems such as greenhouse effect. As a result, high amount of nitrate absorbed by the human body, it causes the formation of nitrosamine compounds known as mutagenic, teratogenic, toxic and carcinogenic (Gupta and Khosla, 2012; Karaşahin, 2014).

Nitrogen is the most leachleached nutrient from the soil. In the leaching, high nitrogen doses and some fertilizer forms are important factors leach (Kant et al. 2006). Most of the nitrogen applied to the soil turns into nitrate $\left(\mathrm{NO}_{3}\right)$ form (Barraclough et al. 1984), rainfall and irrigation water facilitates the movement of nitrate in the soil profile (Ju et al. 2003; İbrikci et al. 2016). This is because clay surfaces and nitrate $\left(\mathrm{NO}_{3}\right)$ are negatively charged and this compound $\left(\mathrm{NO}_{3}\right)$ is soluble. Ammonium $\left(\mathrm{NH}_{4}\right)$ is mostly fixed by soil colloids and therefore, it is assumed that ammonium $\left(\mathrm{NH}_{4}\right)$ is immobile leachand nitrate $\left(\mathrm{NO}_{3}\right)$ is mobile in terms of leaching (Wiklander 1977; Johnsson et al. 1987; Aulakh and Singh 1997; Chowdary 2004).

Nitrate, which moves rapidly in the soil along with the water and mixes with underground water used as drinking water, could cause serious environmental and health problems (Özekici, 2008). The accepteble upper limit ofnitrate and ammonium were determined as $50 \mathrm{mg} \mathrm{L}^{-1}$ and $0.50 \mathrm{mg} \mathrm{L}^{-1}$ in drinking water by Europeann union and Turkey, (Anonymous, 2005; Anonymous, 2010). In the research conducted in Turkey, it was reported that the ratio of nitrogen in groundwater exceeded the specified nitrogen standard for drinking water. Similarly, groundwater samples were taken from 59 points around Nif Mountain, one of the important water resources of İzmir province and it was founded thatthe amount of the nitrate in groundwater was more than $50 \mathrm{mg} \mathrm{L}^{-1}$ (Polat et al. 2007) and in the onather study conducted in 20 wells in Antalya Kumluca region, $\mathrm{NO}_{3}$ concentrates were found cahnged between 246 and $164.91 \mathrm{mg} \mathrm{L}^{-1}$ (Kaplan et al. 1999) and also it was reported in the study conducted in 42 drilled deep well in Erzurum Gümüşhacıköy Aquifer, the $\mathrm{NO}_{3}$ and $\mathrm{NH}_{4}$ concentratons in 8 deep wells used as drinking water were above the drinking water standard (Ersoy and Ersoy, 2007).

In the $75 \%$ of Turkey's erable land it is poor in terms of nitrogen due to leachleaching, erosion and losses in gaseous form (Yetgin, 2010; Karaman, 2012). Therefore, fertilization has an important for sustainable crop production (Sönmez et al. 2008). Nitrogenous fertilizer consumption takes the first place in Turkey (Akdağ and Zengin 2020) and it increases every year, although it varies according to the variety used. For example, the use of nitrogenous fertilizers, which was 6.397,000 tons in 2010, was 8.010,000 tons in 2019 (Anonymous, 2019b).

Turkey is in fourth rank in the world in terms of walnut grower. Kahramanmaraş province is the first rank in walnut production and then it has been spread over a geographical area of the country (Güvenç and Kazankaya, 2019). As walnut production increases year and year throughout the province, nitrogen consumption will be also increases. Increasing nitrogen consumption every year could cause pollution of nature as well as economic losses and threatens human health. Therefore, it is an important issue that needs to be addressed on. In this study, it was aimed to determine the nitrogen leachleaching under precipitation conditions from weighing lysimeter controlled by PLC.

\section{Materials and Methods}

\subsection{Study area}

Study was conducted between in December 2018 and April 2019 atthe Research and Application of of Agricultural Faculty, Sütçü İmam University, Kahramanmaras/ Turkey. The trial area is between $37^{\circ} 35^{\prime} 36$ " north latitude and $36^{\circ} 49^{\prime} 20$ " east longitude and approximately $508 \mathrm{~m}$ above sea level. The average precipitation and temperature are 
$719.7 \mathrm{~mm}$ and $16.6^{\circ} \mathrm{C}$, and the Mediterranean climate is dominant in experimental area (Uzun et al., 2018). The physical and chemical properties of the lysimeter soil are given in Tables 1 and 2. In terms of plant growth, lysimeter soil does not have any negative effects according to physical and chemical analysis.

Table 1. Some physical properties of soil

\begin{tabular}{cccclccc}
\hline $\begin{array}{c}\text { Depth } \\
(\mathbf{c m})\end{array}$ & $\begin{array}{c}\text { Sand } \\
\mathbf{\%}\end{array}$ & $\begin{array}{c}\text { Clay } \\
\mathbf{\%}\end{array}$ & Silt \% & Texture & $\begin{array}{c}\text { Field } \\
\text { capacity Pw } \\
\mathbf{( \% )}\end{array}$ & $\begin{array}{c}\text { Permanent } \\
\text { wilting point } \\
\text { Pw (\%) }\end{array}$ & $\begin{array}{c}\text { Bulk density } \\
\left.\mathbf{( g ~ c m}^{-3}\right)\end{array}$ \\
\hline $0-30$ & 49.50 & 20.32 & 30.18 & Clay Loam (CL) & 35.04 & 22.39 & 1.38 \\
$30-60$ & 36.28 & 23.91 & 39.80 & Clay Loam (CL) & 35.99 & 24.17 & 1.36 \\
$60-90$ & 31.81 & 23.97 & 44.22 & Claye (C) & 41.19 & 20.43 & 1.50 \\
\hline
\end{tabular}

Table 2. Some chemical properties of soil

\begin{tabular}{|c|c|c|c|}
\hline Layer Depth (cm) & $0-30$ & $30-60$ & $60-90$ \\
\hline Saturation point (\%) & 81 & 89 & 92 \\
\hline $\mathrm{pH}$ & 8.05 & 7.83 & 7.70 \\
\hline $\mathrm{EC} \mathrm{dS} \mathrm{m} \mathrm{m}^{-1}$ & 1.00 & 0.90 & 0.94 \\
\hline Lime \% & 9.03 & 10.64 & 13.87 \\
\hline Organic Matter $\%$ & 1.58 & 1.25 & 1.22 \\
\hline Useful Phosphorus $\left(\mathrm{P}_{2} \mathrm{O}_{5}\right) \mathrm{kg} \mathrm{da}^{-1}$ & 4.31 & 3.07 & 1.45 \\
\hline Useful Potassium $\left(\mathrm{K}_{2} \mathrm{O}\right) \mathrm{kg} \mathrm{da}^{-1}$ & 68.04 & 54.84 & 47.24 \\
\hline Useful Calcium (Ca) $\mathrm{mg} \mathrm{kg}^{-1}$ & $11,285.19$ & $11,029.68$ & $10,872.21$ \\
\hline Useful Magnesium (Mg) mg kg-1 & 501.13 & 502.69 & 503.76 \\
\hline Exchangeable Sodium (Na) $\mathrm{mg} \mathrm{kg}^{-1}$ & 54.50 & 38.40 & 55.42 \\
\hline Useful Iron $(\mathrm{Fe}) \mathrm{mg} \mathrm{kg}^{-1}$ & 0.46 & 0.52 & 0.43 \\
\hline Useful Manganese (Mn) $\mathrm{mg} \mathrm{kg}^{-1}$ & 0.82 & 0.76 & 1.03 \\
\hline Useful Copper $(\mathrm{Cu}) \mathrm{mg} \mathrm{kg}^{-1}$ & 1.21 & 1.15 & 1.16 \\
\hline Useful Zinc (Zn) $\mathrm{mg} \mathrm{kg}^{-1}$ & 0.71 & 1.93 & 2.08 \\
\hline
\end{tabular}

\subsection{Lysimeter tank}

Lysimeter was constructed in 2018 to determine the water consumption of the walnut plant (Figure 1). Tank of lysimeter is cylindrical, $113 \mathrm{~cm}$ in diameter and $130 \mathrm{~cm}$ in depth and sat on four legged stand with $10 \mathrm{~cm}$ height. A stainless chrome-nickel coated $0.5 \mathrm{~cm}$ mesh sieve is placed in bottom of tank to facilitate the leakage of water and to prevent the mixing of soil. There is a $115 \mathrm{~cm}$ deep soil layer in the lysimeter. Surface flow was prevented by leaving a $5 \mathrm{~cm}$ gap above the lysimeter. It was tried to minimize its exposure to solar radiation and environmental temperature by covering it with glass wool with a thickness of $10 \mathrm{~cm}$. Glass wool is also protected from environmental effects by wrapping it with a nylon cover. There is a 3-year-old Maraş 18 variety walnut tree on it, which was planted in the year of 2018 .

\subsection{Weighbridge}

Lysimeter is placed on an electronic scale with four tons capacity, $0.2 \mathrm{~kg}$ accuracy, 4 load cells, converter board and RS232 output.

\subsection{Automation panel and PLC}

The panel consists of 1 PLC device, 1 power supply, 4 terminal groups and 3 automatic fuses. In the study, a PLC with PM564-TP-ETH type CPU was used to measure precipitation and drainage water with the signals receiving from digital pluviometers and to save daily measurement values to the SD card. 


\subsection{Pluviometer}

In the research, 2 digital pluviometers with buckets and with $20.000 \mathrm{~mm}^{2}$ funnal area were used. One of them measuring precipitation was placed on the weather station pole, and the other one measuring the drainage was placed in the drainage tank (Figure 1).

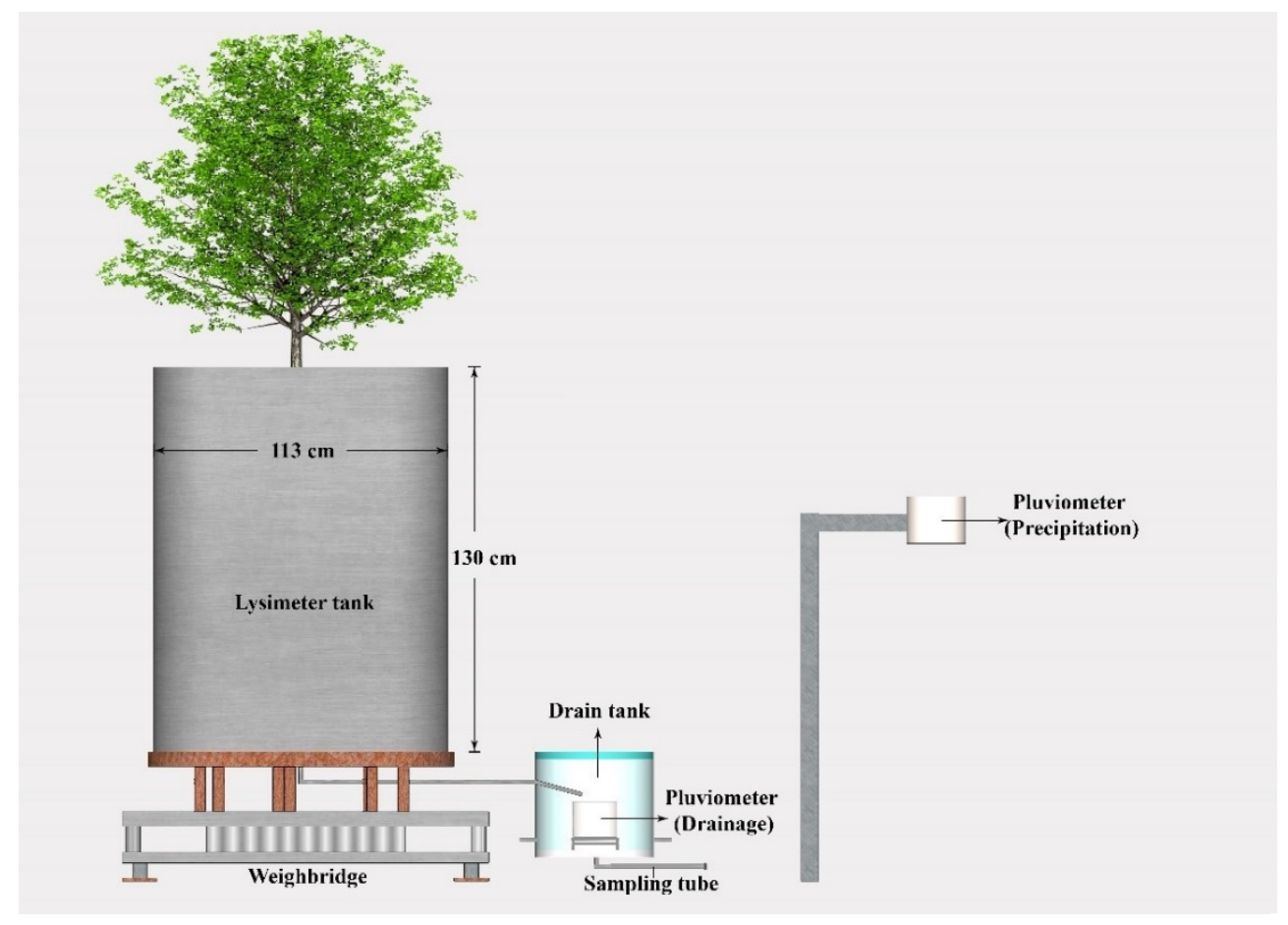

Figure 1. Lysimeter system

\subsection{Drain tank}

To directly measure the drained water from the lysimeter by pluviometer, a plastic barrel of 25 liters $(27 \mathrm{~cm}$ in diameter and $50 \mathrm{~cm}$ in height) with 1 inlet and 4 outlets was utilized and the pluviometer sat on a stand of $14 \mathrm{~cm}$ height in tank. The three holes of them were drilled at a height of $5 \mathrm{~cm}$ on the bottom-side of the tank to accumulate at least 1 liter of water inside the tank and to provid excess water flow freely. The rest outlet on the center of the bottom was connected to one end of the pipe of 1 meter lenght, which the other end was plugged with a stoppper. Openning the plugged end, water samples for nitrogen anlysis was collected with plastic bottles of $500 \mathrm{ml}$ (Figure 2).

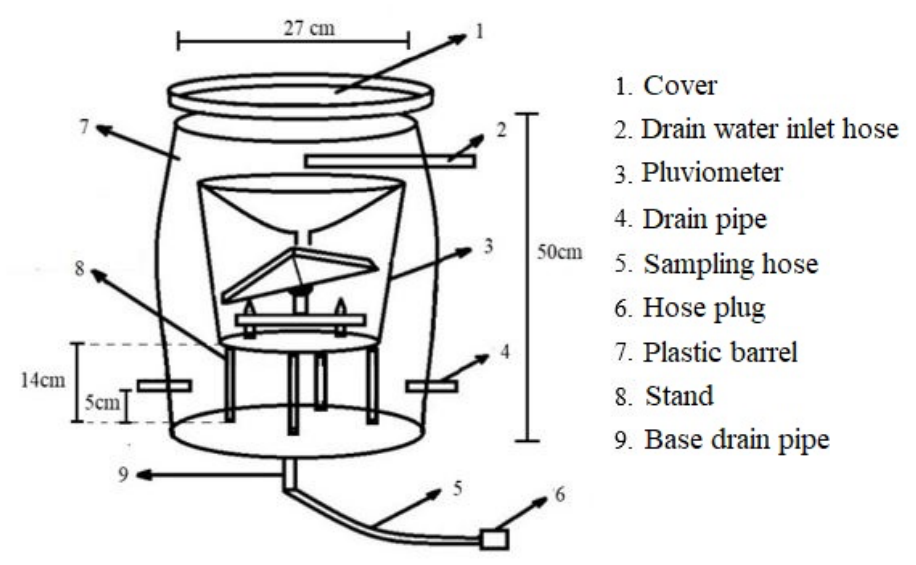

Figure 2. Drain tank and pluviometer 


\section{7. fertilizer application}

On 24 November 2018, 300 gr Diammonium Phosphate (DAP) fertilizer was applied to the lysimeter soil. DAP is a compound fertilizer containing two important plant nutrients such as nitrogen and phosphorus. The compound fertilizer contains $18 \%$ nitrogen $(\mathrm{N})$ and $46 \%$ phosphorus (phosphorus pentoxide, $\mathrm{P} 2 \mathrm{O}$ ). The nitrogen content of the fertilizer is in the form of ammonium $\left(\mathrm{NH}_{4}{ }^{+}\right)$(Güzel et al., 2008; Anonymous, 2019a). The applied fertilizer was mixed with the hoe and covered with soil. Nitrogen inputs and outputs per hectare were calculated by assuming arrangement of the $10 \times 10 \mathrm{~m}$ walnut.

\subsection{Precipitation and drainage measurements}

The research started on November 25, 2018, but 5-day records for November are included in December. The automation system measured amount of rainfall and drainage and recorded them to the SD card every night at 23:59 o'clock in the experimental period of 157 day. In the period, the beginning and end of the months were determined according to the effect of monthly rainfall on the drainage of the next month. The start and end of months were given in Table 3. Monthly amounts of rainfall and drainage were determined based on the months.

Table 3. Starting and ending of the months

\begin{tabular}{ll}
\hline Months & Date range \\
\hline December & $25.11 .2018-29.12 .2018$ \\
January & $30.12 .2018-29.01 .2019$ \\
February & $30.01 .2019-02.03 .2019$ \\
March & $03-31.03 .2019$ \\
April & $01-30.04 .2019$ \\
\hline
\end{tabular}

The amount of precipitation (P) and drainage (qi) were calculated on a daily basis using Equation 1 (Gençoğlan et al. 2020).

$$
P=\frac{S . H}{A}
$$

Where, $\mathrm{P}$; daily precipitation ( $\mathrm{mm}), \mathrm{S}$; tipping number of bucket, $\mathrm{H}$; bucket tipping volume $\left(\mathrm{mm}^{3}\right)$ and $\mathrm{A}$; the funnal surface area of pluviometer $\left(\mathrm{mm}^{2}\right)$. The funnal surface area (A) of precipitation pluviometer for is 20.000 $\mathrm{mm}^{2}$. Since the drainage pluviometer measures the water leaching from the lysimeter, the funnal surface area is $10^{6} \mathrm{~mm}^{2}$, which is the lysimeter surface area. Tipping volumes of buckets of precipitation and drainage pluviometers were determined as $5.100 \mathrm{~mm}^{3}$ and $3.245 \mathrm{~mm}^{3}$, respectively, by calibration.

\subsection{Water and soil analysis}

The first soil sample from lysimeter was taken on 25.11.2018 before fertilizer application and the last one on 15.05.2019. The first water sample leaching from the lysimeter by drainage after rains were taken on 03.12.2018 and the last sample on 08.04.2019. The leaching completely ended on 11.04.2019 and there was no leaching after this date. Therefore, while calculating the amount of the leached nitrogen, the amount of precipitation and drainage that occurred until 11.04.2019, when the leakage from the lysimeter was completely finished, was taken into account.

Water samples were taken from the water accumulated in the drainage tank after daily rainfall. After the samples were taken with $500 \mathrm{ml}$ plastic bottles, and labeled with their dates and then stored at $+4^{\circ} \mathrm{C}$ in a refrigerator. For nitrogen analysis, the Kjeldahl method was applied to the samples in 3 replication (Bremner and Mulvaney, 1982; Kacar, 2009). Nitrogen concentration values $\left(\mathrm{NO}_{3}, \mathrm{NH}_{4}, \mathrm{mg} \mathrm{L}^{-1}\right)$ were calculated as load values $\left(\mathrm{NO}_{3}-\mathrm{N}\right.$, $\mathrm{NH}_{4}-\mathrm{N}$, as kg ha- ${ }^{-1}$. $\mathrm{NO}_{3}+\mathrm{NH}_{4}$ total nitrogen concentration (mineral nitrogen) represents $\mathrm{NO}_{3}-\mathrm{N}+\mathrm{NH}_{4}-\mathrm{N}$ the total nitrogen load $(\mathrm{N})$. 
The concentrations of $\mathrm{NO}_{3}$ and $\mathrm{NH}_{4}$ in each sample were calculated using Equation 2.

$$
c_{i}=\frac{t . s}{r} 20 . f
$$

Where, ci; the amount of concentration $\left(\mathrm{mg} \mathrm{L}^{-1}\right)$, $\mathrm{t}$; the amount of witness solution $\left(50 \mathrm{ml}^{-1}\right)$, s; amounts of standard acid (mg) used in the titrated $50 \mathrm{ml}$ sample distillates, $\mathrm{r}$; standard amount of acid (mg) used in the titrated $50 \mathrm{ml}$ witness distillates and f refers to the dilution factor. The dilution factor (f) is used only in calculations in soil samples. In the calculation of nitrogen concentrations in soil samples, soil of $5 \mathrm{mg}$ was completed to $50 \mathrm{mg}$ by extraction application. Therefore, Equation 1 is multiplied by the dilution factor (f) $50 / 5=10$ for soil samples. In the calculations of water samples, $\mathrm{f}$ is taken as 1 .

Monthly $\mathrm{NO}_{3}$ and $\mathrm{NH}_{4}$ concentrations were calculated using Equation 3, for the monthly precipitation in experimental period.

$$
C_{j}=Q^{-1} \sum_{i=1}^{n} c_{i} \cdot q_{i_{i}}
$$

Where, $\mathrm{Cj}$; monthly nitrogen $\left(\mathrm{NO}_{3}+\mathrm{NH}_{4}\right)$ concentration $\left(\mathrm{mg} \mathrm{L}^{-1}\right), \mathrm{Q}$; the total monthly amount of drainage water $(\mathrm{mm})$, $\mathrm{n}$; monthly number of samples, ci; the nitrogen concentration $\left(\mathrm{mg} \mathrm{L}^{-1}\right)$ and qi amount of the drained water after rainfall $(\mathrm{mm})$. Monthly total nitrogen loads $\left(\mathrm{NO}_{3}-\mathrm{N}+\mathrm{NH}_{4}-\mathrm{N}\right)$ were calculated using Equation 4.

$$
L_{j}=0.01 . C_{j} \cdot Q \cdot k
$$

Where, $\mathrm{L}_{\mathrm{j}}$; monthly nitrogen load $\left(\mathrm{kg} \mathrm{N} \mathrm{ha}^{-1}\right), \mathrm{C}_{\mathrm{j}}$; monthly nitrogen concentration $\left(\mathrm{mg} \mathrm{L}^{-1}\right)$, Q; the total monthly amount of drained water $(\mathrm{mm}), \mathrm{k}$; the conversion coefficient. The oefficients were found by proportioning the atomic weight of the nitrogen element $(\mathrm{N})$ to the molecule weights of the $\mathrm{NO}_{3}$ and $\mathrm{NH}_{4}$. These values are 0.225 for $\mathrm{NO}_{3}$ and 0.776 for $\mathrm{NH}_{4}$.

Regression analyzes were made between rainfall, drainage and leached nitrogen amounts to estimate the amount of nitrogen leaching from the lysimeter soil above the field capacity after rainfall. In the equations, total nitrogen load $\mathrm{Np}$ for precipitation and $\mathrm{Nd}$ for drainage $\left(\mathrm{kg} \mathrm{N} \mathrm{ha}^{-1}\right)$ were dependent variables, and amounts of precipitation $(\mathrm{P})$ and drainage $(\mathrm{d})(\mathrm{mm})$ were taken as independent variables.

\section{Results and Discussion}

\subsection{Precipitation and drainage water}

The automation system made 157 measurements with 24 hour intervals to measure the water leaching from the lysimeter after rainfall in rainy of 97 days.

During experiment, a total of $868.1 \mathrm{~mm}$ of precipitation and $686.6 \mathrm{~mm}$ of drainage were measured and given in Table 5. The measured precipitation was well above the $533 \mathrm{~mm}$ average rainfall of Kahramanmaraş province for the same and long term (Anonymous, 2022). The highest precipitation and drainage was in December with 264.1 and $221.4 \mathrm{~mm}$, and the lowest with 48.4 and $20.7 \mathrm{~mm}$ in April, respectively. In the table, there was parallelism between the amount of precipitation falling on lysimeter and drainage water from the lysimeter. The reasons for the parallelism were; being the soil moisture above the field capacity during the experimental periods and having the high precipitation causing the increased water leaching (İbrikçi et al. 2016), and degrading to a certain extent structure of the soil filled the lysimeter and being no runoff from lysimeter.

\subsection{Nitrogen analysis results}

Nitrogen analysis showed that, only $\mathrm{NH}_{4}$ was obtained in the soil samples but $\mathrm{NO}_{3}$ was not found. At the beginning of the experiment, the $\mathrm{NH}_{4}$ of $68.6 \mathrm{mg} \mathrm{kg}^{-1}\left(146.8 \mathrm{~kg} \mathrm{~N} \mathrm{ha}^{-1}\right)$ in total was detected from the soil samples. Nitrogen in the form of $\mathrm{NH}_{4}$ of $1.9 \mathrm{mg} \mathrm{kg}^{-1}\left(4.2 \mathrm{~kg} \mathrm{~N} \mathrm{ha}^{-1}\right)$ was applied externally to the lysimeter soil. Thus, at the beginning of study in the soil, the both nitrogen $\left.68.6 \mathrm{mg} \mathrm{kg}^{-1}\left(146.8 \mathrm{~kg} \mathrm{~N} \mathrm{ha}^{-1}\right)+1.9 \mathrm{mg} \mathrm{kg}^{-1}\left(4.2 \mathrm{~kg} \mathrm{~N} \mathrm{ha}^{-1}\right)\right)$ 
made a total of $70.5 \mathrm{mg} \mathrm{kg}^{-1}\left(151.03 \mathrm{~kg} \mathrm{~N} \mathrm{ha}^{-1}\right) \mathrm{NH}_{4}$ (Table 4). At the end of the experiment, a total of $20.7 \mathrm{mg}$ $\mathrm{kg}^{-1}\left(44.3 \mathrm{~kg} \mathrm{ha}^{-1}\right)$ nitrogen was determined in the form of ammonium in the soil.

According to this value, it was determined that $70.7 \%\left(106.7 \mathrm{~kg} \mathrm{~N} \mathrm{ha}^{-1}\right)$ of the total nitrogen was lost in the top soil depth of $20 \mathrm{~cm}$ at the end of the experiment (Table 4).

Table 4. Amounts of nitrogen in lysimeter soil

\begin{tabular}{|c|c|c|}
\hline & $\mathrm{mg} \mathrm{N} \mathrm{kg}^{-1}$ & kg N ha ${ }^{-1}$ \\
\hline December 2018 & 70.5 & 151.03 \\
\hline April 2019 & 20.7 & 44.3 \\
\hline Lost Nitrogen & 49.8 & 106.7 \\
\hline Leaching & 6.8 & 12.7 \\
\hline
\end{tabular}

Drainage water analysis showded that concentrations of $\mathrm{NO}_{3}, \mathrm{NH}_{4}$ and mineral nitrogen $\left(\mathrm{NO}_{3}+\mathrm{NH}_{4}\right)$ varied between 4.5-8.2 $\mathrm{mg} \mathrm{L}^{-1}, 0.1-1.1 \mathrm{mg} \mathrm{L}^{-1}$ and 4.7-9.0 $\mathrm{mg} \mathrm{L}^{-1}$, respectively (Table 5). In drainage water samples, $\mathrm{NO}_{3}$ concentrations were highest with $8.2 \mathrm{mg} \mathrm{L}^{-1}$ in March and the lowest with $4.5 \mathrm{mg} \mathrm{L}^{-1}$ in January. $\mathrm{NH}_{4}$ concentrations were determined to be the highest $\left(1.1 \mathrm{mg} \mathrm{L}^{-1}\right)$ in December and the lowest $\left(0.1 \mathrm{mg} \mathrm{L}^{-1}\right)$ in January. Mineral nitrogen $\left(\mathrm{NO}_{3}+\mathrm{NH}_{4}\right)$ concentrations were found the highest $\left(9.0 \mathrm{mg} \mathrm{L}^{-1}\right)$ in March and the lowest (4.7 $\mathrm{mg} \mathrm{L}^{-1}$ ) in January. During the trial season, monthly $\mathrm{NO}_{3}-\mathrm{N}$ loads in the drainage water varied between $0.4-3.6 \mathrm{~kg}$ $\mathrm{N} \mathrm{ha}^{-1}, \mathrm{NH}_{4}-\mathrm{N}$ loads $0.1-1.9 \mathrm{~kg} \mathrm{ha}^{-1}$ and total nitrogen $(\mathrm{N})$ loads between $0.5-5.4 \mathrm{~kg} \mathrm{~N}^{-1}$. In water samples, $\mathrm{NO}_{3}-$ $\mathrm{N}$ loads were the highest $\left(3.6 \mathrm{~kg} \mathrm{~N} \mathrm{ha}^{-1}\right)$ in December and the lowest $\left(0.4 \mathrm{~kg} \mathrm{~N} \mathrm{ha}^{-1}\right)$ in April; $\mathrm{NH}_{4}-\mathrm{N}$ loads were determined the highest $\left(1.9 \mathrm{~kg} \mathrm{~N} \mathrm{ha}^{-1}\right)$ in December and the lowest $\left(0.1 \mathrm{~kg} \mathrm{~N} \mathrm{ha}^{-1}\right)$ in April. According to these results, the highest amount of nitrogen $(\mathrm{N})$ leached from the lysimeter by the effect of the precipitation in December (5.4 $\left.\mathrm{kg} \mathrm{N} \mathrm{ha}^{-1}\right)$ and the lowest $\left(0.5 \mathrm{~kg} \mathrm{~N} \mathrm{ha}^{-1}\right)$ in April.

The total leached amount of nitrogen was found to be $12.7 \mathrm{~kg} \mathrm{~N} \mathrm{ha}^{-1}$. This figure was equal to $8.4 \%$ of the total $\left(151.03 \mathrm{~kg} \mathrm{~N} \mathrm{ha}^{-1}\right)$ nitrogen $(\mathrm{N})$ in the soil at the start of experiment and $11.9 \%\left(12.7 \mathrm{~kg} \mathrm{~N} \mathrm{ha}^{-1}\right)$ of the total nitrogen loss $\left(106.7 \mathrm{~kg} \mathrm{ha}^{-1}\right)$. Apart from the $12.7 \mathrm{~kg} \mathrm{~N} \mathrm{ha}^{-1}$ leaching loss, reasons such as ammonium fixation, denitrification, volatization (Güzel et al. 2008) and walnut plant usage are thought to be effective in the loss of $106.7 \mathrm{~kg} \mathrm{~N} \mathrm{ha}^{-1}$ nitrogen. Linn and Doran (1984) reported that denitrification may cause nitrogen loss between 2 $73 \%$ in water-saturated soils, Denmead et al. (2005) found that $0.220 \mathrm{~kg} \mathrm{ha}^{-1}$ nitrogen oxide is lost per day when the water-filled pore space of a sugarcane soil was between $60-80 \%$, similarly when the pore space is between 30 $60 \%$ this value is $0.096 \mathrm{~kg} \mathrm{ha}^{-1}$ per day. Özbek et al. (2007), noted that $30-50 \%$ of the nitrogen applied to the soil can be lost by denitrification. In addition, it was estimated that some of the fertilizer removed from the soil by ammonia $\left(\mathrm{NH}_{3}\right)$ volatization, which was mixed in the first $5 \mathrm{~cm}$ soil. Güzel et al. (2008) reported that the ammonia loss was at maximum when the moisture content of the top soil was in the field capacity and additionaly this loss was reported to reach up to $70 \%$ when the soil dried gradually with evaporation in laboratory conditions, and.

Table 5. Nitrogen concentrations and load values leached with drainage

\begin{tabular}{|c|c|c|c|c|c|c|c|c|}
\hline \multirow{2}{*}{ Months } & \multicolumn{3}{|c|}{$\begin{array}{c}\text { Concentrations } \\
\left(\mathrm{mg} \mathrm{L}^{-1}\right)\end{array}$} & \multicolumn{3}{|c|}{ Loads $\left(\mathrm{kg} \mathrm{ha}^{-1}\right)$} & \multirow{2}{*}{$\frac{\text { Precipitation }}{(\mathrm{mm})}$} & \multirow{2}{*}{$\frac{\text { Drainage }}{(\mathrm{mm})}$} \\
\hline & $\mathbf{N H}_{4}$ & $\mathrm{NO}_{3}$ & Total & $\mathbf{N H}_{4}-\mathrm{N}$ & $\mathrm{NO}_{3}-\mathrm{N}$ & Total & & \\
\hline December & 1.1 & 7.2 & 8.2 & 1.9 & 3.6 & 5.4 & 264.4 & 221.4 \\
\hline January & 0.3 & 4.5 & 4.7 & 0.5 & 2.5 & 3.0 & 259.0 & 247.6 \\
\hline February & 0.1 & 6.3 & 6.4 & 0.1 & 1.6 & 1.7 & 154.8 & 114.4 \\
\hline March & 0.8 & 8.2 & 9.0 & 0.5 & 1.5 & 2.0 & 141.8 & 82.5 \\
\hline April & 0.9 & 8.0 & 8.9 & 0.2 & 0.4 & 0.5 & 48.4 & 20.7 \\
\hline Total & 0.6 & 6.2 & 6.8 & 3.1 & 9.6 & 12.7 & 868.1 & 686.6 \\
\hline
\end{tabular}

As seen in Table 5, concentration and load values were $8.2 \mathrm{mg} \mathrm{L}^{-1}$ and $5.4 \mathrm{~kg} \mathrm{ha}^{-1}$, respectively in December which was the first month of the study. Nitrogen concentrations dropped to $4.7 \mathrm{mg} \mathrm{L}^{-1}$ in January in which precipitation was $259 \mathrm{~mm}$. Concentration values started to increase with the decrease of rainfall after February. 
Karakuş \&Gençoğlan \& Gençoğlan Determination of Nitrogen Leaching Under Precipitaiton Conditions from Weighted Lysimeter Planted Walnut (Juglans regia L.) İbrikçi et al. (2016) reported that the decrease in drainage due to rainfall in winter months increased nitrogen concentrations. In addition, In addition, it is thought that since after this month soil temperature increased accelerated nitrification and may have increased the nitrogen concentrations(Muchow, 1994; Başer, 2006).

$76 \%$ of the leached $12.7 \mathrm{~kg} \mathrm{~N} \mathrm{ha}^{-1}$ nitrogen is in the form of nitrate $\left(9.6 \mathrm{~kg} \mathrm{~N} \mathrm{ha}^{-1}\right)$ and $24 \%\left(3.1 \mathrm{~kg} \mathrm{~N} \mathrm{ha}^{-1}\right)$ in the form of ammonium. Barraclough et al. (1984) reported that the nitrate leached in the ranging of 9-75\% in different fertilizer dosage applications. Ju et al. (2003) found that excessive rainfall is a factor that facilitates the movement of nitrate in the profile. İbrikci et al. (2016) reported that the plant pattern, precipitation and the amount of irrigations have important effect on the nitrate concentration in the drainage water.

The reason of nitrogen leaching by the effect of rainfall is that nitrate is a soluble and negatively charged and called the mobile ion in the soil. So, it moves naturally towards deeper of the soil along with the drainage water and finally contemnated the ground water (Özekici, 2008; Anonymous, 2013b). Therefore, nitrogen loss was by the mean of nitrogen by leaching from the soil. On the other hand, ammonium is assumed to be immobile as it is largely fixed to soil colloids and is not easily transported by water flow except under special conditions (Wiklander 1977; Johnsson et al. 1987; Aulakh and Singh 1997; Chowdary 2004; Karnez et al. 2013; İbrikci et al. 2012, 2015).

The linear regression equations were found as $\mathrm{N}_{\mathrm{p}}=0.015 \mathrm{p}+0.011\left(\mathrm{R}^{2}=0.745\right)$ and $\mathrm{N}_{\mathrm{d}}=0.015 \mathrm{~d}+0.228\left(\mathrm{R}^{2}\right.$ $=0.722$ ), respectively (Figure 3). According to the $\mathrm{R}$ squars, precipitation has the power to explain the leached nitrogen by approximately $75 \%$ and drainage by $72 \%$. These equations showed that the leached amount of nitrogen $\left(\mathrm{N}_{\mathrm{P}}\right)$ and nitrogen $\left(\mathrm{N}_{\mathrm{d}}\right)$ after rains could be estimated. As can be seen from the equation in Figure 3, when the precipitation of $20 \mathrm{~mm}$ occured, for example, the leached amount of nitrogen was $0.31 \mathrm{~kg} \mathrm{ha}^{-1}$, and with drainage of $20 \mathrm{~mm}, 0.53 \mathrm{~kg} \mathrm{ha}^{-1}$ However, when rainfall and drainage stop $(\mathrm{P}=0)$, it is estimated that some nitrogen $\left(\mathrm{N}_{\mathrm{p}}=\right.$ $0.011 \mathrm{~kg} \mathrm{ha}^{-1}$ and $\mathrm{N}_{\mathrm{d}}=0.228 \mathrm{~kg} \mathrm{ha}^{-1}$ ) is leached away. Hess et al. (2020) reported in their study that the increase in the amount of precipitation increased $\mathrm{N}$ leaching and this situation had economic and environmental damages.
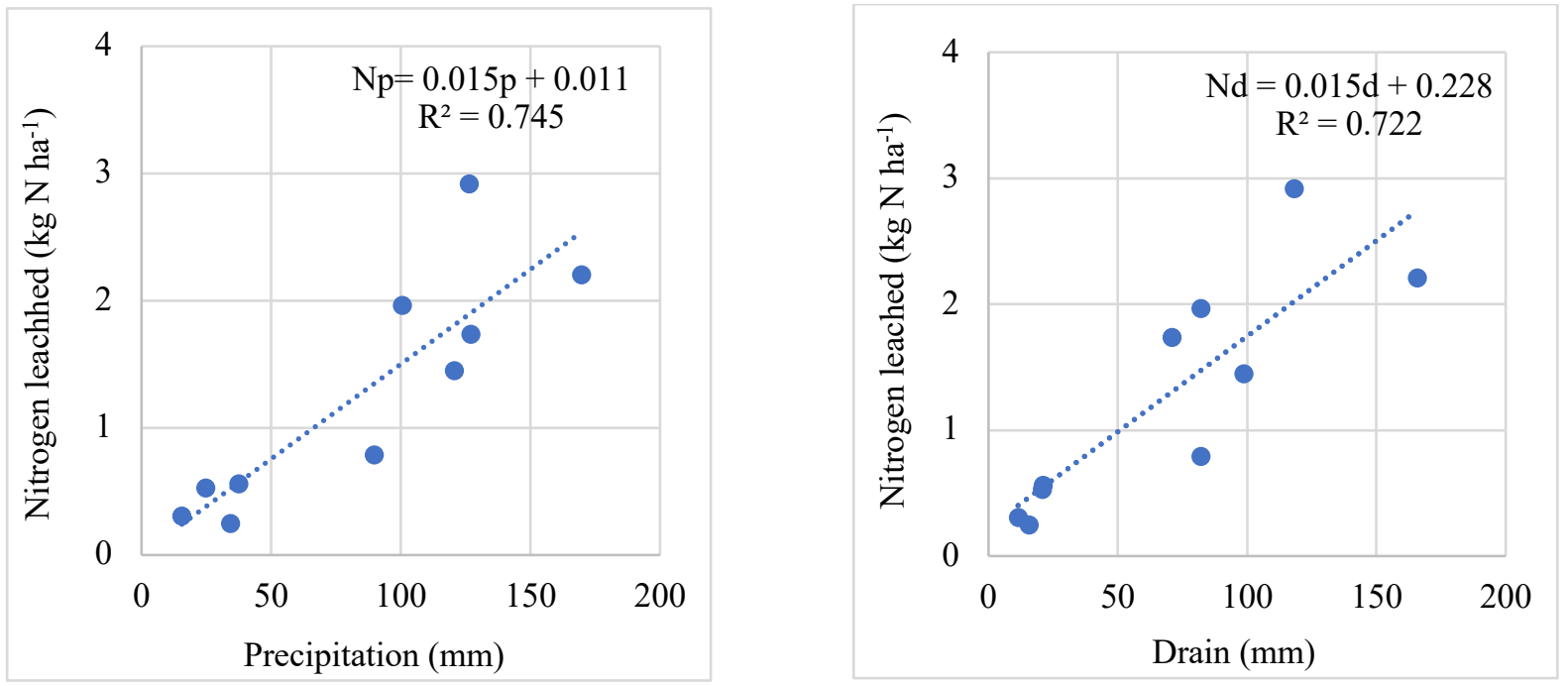

Figure 3. Relationships between precipitation, drainage, and soil leached nitrogen (N)

\section{Conclusions}

The automation system created made 157 measurements with 24-hour intervals to measure the water leaching from the lysimeter after rainfall in the rainy of 97days. The system recorded $868.1 \mathrm{~mm}$ of rainfall and $686.6 \mathrm{~mm}$ of drainage during the period. The highest rainfall was $264.1 \mathrm{~mm}$ in December 2018, the lowest precipitation was $48.4 \mathrm{~mm}$ in April 2019, the highest drainage was $247.6 \mathrm{~mm}$ in January 2019, and the lowest was $20.7 \mathrm{~mm}$ in April 2019. It was determined that $12.7 \mathrm{~kg} \mathrm{~N} \mathrm{ha}^{-1}$ nitrogen was leached along with the drainage water, and this value was $8.4 \%$ of the total nitrogen found in the lysimeter soil at the beginning. Of the leached nitrogen, $24 \%\left(3.1 \mathrm{~kg} \mathrm{~N} \mathrm{ha}^{-1}\right)$ is in the form of ammonium and $76 \%\left(9.6 \mathrm{~kg} \mathrm{~N} \mathrm{ha}^{-1}\right)$ of nitrate. The results showed that applying nitrogenous (N) fertilizer to the soil regardless of seasonal rainfall, would increase nitrogen leaching.

While preparing the fertilization program in agricultural production, the type, dose, fertilization time and form of 
nitrogenous fertilizers should be planned correctly, taking into account the precipitation of the region. If possible, nitrogen fertilizer should not be applied in periods of excessive rainfall or should be applied by splitting. This will provide a significant gain in terms of both protecting human health and contributing to the country's economy by reducing the input costs in production by preventing the environmental and economic impact of nitrogen loss.

\section{Acknowledgment}

This work supported by the Sütçü İmam University Scientific Research Project (Project No:2019 / 02-3 YLS), Türkiye. 


\section{References}

Akdağ, M, N., Zengin, M. (2020). Artan Dozlarda Bakir Sülfat ve Azot Uygulamalarinin Ekmeklik Bugdayda Verim ile Kök ve Kök Bogazi Çürüklügü Hastaligina Etkileri. Journal of Tekirdag Agricultural Faculty, 17(2): 149-161.

Anonymous, (2005). Regulation on Water Intended for Human Consumption, www.resmigazete.gov.tr/eskiler/2005/02/20050217-3.htm, (accessed date:23.09.2019)

Anonymous, (2010). Council Directive 98/83 / EC of 3 November 1998 on the quality of water intended for human consumption. Documents in European Community Environmental Law. C. L 330, pp. 865-878

Anonymous, (2019a). DAP Fertilizer (Diammonium Phosphate), http://www.toros.com.tr/Tr/Dap-Gubre, (accessed date:17.09.2019)

Anonymous, (2019b). Crop Production Statistics, from http://www.tuik.gov.tr/PreTablo.do?alt_id=1001, (accessed date:17.09.2019)

Anonymous,.(2019c). Nitrate Leaching, http://www.far.org.nz/assets/files/uploads/Nitrogen_leaching.pdf, (accessed date: 20.10.2019)

Anonymous, (2022). Official Statistics, https://www.mgm.gov.tr/veridegerlendirme/il-ve-ilceler-istatistik.aspx?m=K.MARAS (accessed date:13.01.2022)

Aulakh, M. S., Singh, B. (1997). Nitrogen losses and fertilizer N use efficiency in irrigated porous soils. Nut. Cyc. Agroecosyst, 47:197-212

Barraclough, D., Geens, E. L., Maggs, J. M. (1984). Fate of fertilizer nitrogen applied to grassland. 11. Nitrogen-15 leaching results, 35: 191199

Başer, K. (2006). Sazlı Dere'nin Azot ve Fosfor Kirliliğinin İzlenmesi ve Etkisinin Irdelenmesi. Marmara Üniversitesi, İstanbul pp. 86

Bremner, J.M., Mulvaney, C.S. (1982). Nitrogen: total, In: Page AL et al. (Ed.). Methods of soil analysis: part 2, 2nd ed., Agronomy monograph 9, ASA, ASSA, Madison, pp. 595-641

Chowdary, V. M., Rao, N. H., Sarma, P. B. S. (2004). A coupled soil water and nitrogen balance model for flooded rice fields in India. Agriculture, Ecosystems \& Environment, 103(3), 425-441.

Çetin, M., Saygin, S., Demir, H. (2020). Tarım Sektörünün Çevre Kirliliği Üzerindeki Etkisi: Türkiye Ekonomisi İçin Bir Eşbütünleşme ve Nedensellik Analizi. Tekirdă̆ Ziraat Fakültesi Dergisi, 17(3), 329-345.

Denmead, O., Macdonald, B., Bryant, G., Reilly, R., Griffith, D., Stainlay, W., White, I., Melville, M. (2005). Gaseous nitrogen losses from acid sulfate sugarcane soils on the coastal lowlands, Proc. Aust. Soc. Sugar Cane Technol, 27: 211-219

Ersoy, A. F., Ersoy, H. (2007). Gümüşhacıköy Akiferi'nde Yer altı suyu Kirliliğinin Modellenmesi. TMMOB Harita ve Kadastro Mühendisleri Odası Ulusal Coğrafi Bilgi Sistemleri Kongresi. 30 Ekim -02 Kasım 2007, KTÜ, Trabzon

Gençoğlan, C., Usta, S., Gençoğlan, S. (2020). Development of a weighting lysimeter system operated by a programmable logic controller (PLC). Mediterranean Agricultural Sciences, 33(1), 107-115.

Gupta, M., L., Khosla, R., (2012). Precision nitrogen management and global nitrogen use eficiency, https://www.ispag.org/proceedings /? Action $=$ abstract $\&$ id $=1013 \&$ search $=$ types, (accessed date: 20.04 .2019$)$

Güvenç, İ., Kazankaya, A. (2019). Türkiye'de ceviz üretimi, dış ticareti ve rekabet gücü. Yüzüncü Yll Üniversitesi Tarım Bilimleri Dergisi 29(3): 418-424.

Güzel, N., Gülüt, K. Y., Büyük, G. (2008). Bitki Besin Elementleri Yönetimine Giriş. Toprak Verimliliği ve Gübreler Adana: Çukurova Üniv. Ziraat Fak. Genel Yayın No: 246. pp.110-203

Hess, L. J., Hinckley, E. L. S., Robertson, G. P., Matson, P. A. (2020). Rainfall intensification increases nitrate leaching from tilled but not no-till cropping systems in the US Midwest. Agriculture, Ecosystems \& Environment, $290,106747$.

İbrikçi, H., Çetin, M., Sağır, H., Mert, U., Gölpınar, M. S., Karnez, E. 2016. Sulu Tarımın Yapıldığı Akarsu Sulama Havzasında Drenajla Oluşan Azot Kayıplarının Zamansal İzlenmesi. Çukurova Tarım ve Gıda Bilimleri Dergisi, 31(3), 153-163.

İbrikci, H., Cetin, M., Karnez, E., Kirda, C., Topcu, S., Ryan, J., Oztekin, E., Dingil, M., Korkmaz, K., Oguz, H. (2012). Spatial and temporal variability of groundwater nitrate concentrations in irrigated Mediterranean agriculture. Communications in soil science and plant analysis, 43(1-2), 47-59.

Ibrikci, H., Cetin, M., Karnez, E., Flügel, W. A., Tilkici, B., Bulbul, Y., \& Ryan, J. (2015). Irrigation-induced nitrate losses assessed in a Mediterranean irrigation district. Agricultural Water Management, 148, 223-231.

Johnsson, H., Bergstrom, L., Jansson, P. E., \& Paustian, K. (1987). Simulated nitrogen dynamics and losses in a layered agricultural soil. Agriculture, Ecosystems \& Environment, 18(4), 333-356.

Ju, X. T., Liu, X. J., \& Zhang, F. S. (2003). Accumulation and movement of $\mathrm{NO}_{3}{ }^{--N}$ in soil profile in winter wheat-summer maize rotation system. Acta Pedologica Sinica, 40(4), 538-546.

Kaçar, B. 2009. Toprak Analizleri. Nobel Yayın Dağıtım, ISBN: 978-605-320-430-5, Ankara, 614s. 
Kant, C., Aydın, A., Barik, K. (2006). Erzurum Daphan ve Pasinler Ovası Toprak Örneklerine Suya Doygun Koşullarda Uygulanan Değişik Azotlu Gübrelerin Çeltik Bitkisinin Gelişimine, Mineral İçeriğine, Besin Maddesi Alımı ve Yıkanmasına Etkisi. Atatürk Üniversitesi Ziraat Fakültesi Dergisi, 37(2), 145-152.

Kaplan, M., Sönmez, S., Tokmak, S. (1999). The nitrate content of well waters in the Kumluca region-Antalya. Turkish Journal of Agriculture and Forestry, 23(3), 309-314.

Karaman, R. (2012). Bitki Besleme. Gübretaş Rehber Kitaplar Dizisi: 2, Çorum.

Karaşahin, M. (2014). Bitkisel üretimde azot alım etkinliği ve reaktif azotun çevre üzerine olumsuz etkileri. Akademik Platform Mühendislik ve Fen Bilimleri Dergisi, 2(3), 15-21.

Karnez, E., İbrikci, H., Cetin, M., Ryan, J., Dingil, M., Oztekin, E., Korkmaz, K. (2013). Implications of profile mineral nitrogen in an irrigated project area of southern Turkey. Communications in soil science and plant analysis, 44(1-4), 783-793.

Linn, D. M., Doran, J. W. (1984). Effect of water-filled pore space on carbon dioxide and nitrous oxide production in tilled and nontilled soils. Soil Science Society of America Journal, 48(6), 1267-1272.

Muchow, R. C. (1994). Effect of nitrogen on yield determination in irrigated maize in tropical and subtropical environments. Field Crops Research, 38(1), 1-13.

Müftüoğlu, N. M., Demirer, T. (1998). Toprakta azot bilançosu. Atatürk Üniversitesi Ziraat Fakültesi Dergisi, 29(1).

Özbek, H., Kaya, Z., Gök, M., Kaptan, H. (2007). Toprak Bilimi. Ç.Ü. Ziraat Fakültesi Yayınları, No: 73. Ders Kitapları Yayın No: A-16, Adana pp. 433-456

Özekici, B. (2008). Damla Sulama Yönteminde Su ve Gübre Tasarrufu. Sulama Drenaj Konferansı. 10 - 11 Nisan 2008, Adana, DSİ VI. Bölge Müdürlüğü, pp. 46-52

Polat, R., Elçi, A., Şimşek, C., \& Gündüz, O. (2007). İzmir-Nif dağı çevresindeki yeraltı suyu nitrat kirliliği boyutunun mevsimsel değerlendirilmesi. 7. Ulusal Çevre Mühendisliği Kongresi (2007), İzmir, Türkiye.

Prakasa, Rao., S., Puttanna K (2000). Nitrates, agriculture and environment. Current Science, 79 (9): 1163-1168

Sönmez, İ., Kaplan, M., Sönmez, S. (2008). Kimyasal gübrelerin çevre kirliliği üzerine etkileri ve çözüm önerileri. Derim, 25(2), 24-34.

Sünal, S. (2012). Türkiye’ de Tarımsal Kaynaklı Yer altı Suyu Nitrat Kirliliği. Türk Bilimsel Derlemeler Dergisi, 5(2): 116-118

Uzun, A., Palabaş, Uzun, S., Korkmaz, S. Y. (2018). Kahramanmaraş Sütçü İmam Üniversitesi, Avşar Yerleşkesi Tohumlu Bitkilerinin Çeşitliliği ve Sistematiği. Kahramanmaraşs Sütçü Imam Üniversitesi Tarım ve Doğa Dergisi, 21(6): 854-874

Wiklander, L. (1977). Leaching of Plant Nutrients in Soils: IV. Contents in Drainage Water and Ground Water. Acta Agriculturae Scandinavica, 27(3), 175-189.

Yetgin, M, A. (2010). Organic Fertilizers and Its Importance, http://www.samsun.tarimorman.gov.tr/Belgeler/Yayinlar/Kitaplarimiz/organik_guberler_ve_onemi.pdf, (accessed date:27.10.2019) 